УДК 341

DOI https://doi.org/10.32849/2663-5313/2020.11.51

\title{
Олеся Проценко,
}

студентка Vкурсу

Слідчо-криміналістичного інституту

Національного юридичного університету імені Ярослава Мудрого

\section{МІГРАЦЙНА ПОЛІТИКА ЄВРОПЕЙСЬКОГО СОЮЗУ}

Євросоюз захищає право людей на свободу пересування як однієї із ключових демократичних иінностей та невід'ємного природного права, тому його міграційна політика спрямована на забезпечення иієї иінності. Відмова від иієї иінності, створення обмежень пересування призведе до підриву всього Європейського Союзу як інтеграчійного об'єднання, бо залишеться лише свобода пересування товарів та послуг, а Європейський Союз перетвориться на суто митний союз. До того ж ие негативно вплине на репутаиію Союзу як демократичного проєкту інтеграиії держав та захисника демократичних иінностей. Відновлення внутрішніх кордонів у Європейському Союзі як засіб захисту від негативних наслідків міграиії руйнує солідарність держав, підриває їхню відкритість до співпрачі й обміну, спричиняє ізоляцію держав усередині Європейського Союзу, підриває приниип свободи руху в Свросоюзі. Відмова від внутрішнього контролю на кордоні в рамках Шенгенської угоди 2006 року обмежила державний суверенітет на користь свободи пересування, держави погодилися на таке обмеження, розуміли необхідність такого кроку, його важливість у рамках інтеграиії. То чому зараз вони готові відійти від такої позиції та вибрати ізоляційний курс? Здається, тому що ие найшвидший спосіб реагування на міграчійну кризу, яка виникла внаслідок того, що крайни Шенгенської зони стерли внутрішні кордони без створення необхідної правової й інституційної основи та без укладання домовленостей щодо створення колективних інституиій захисту зовнішніх кордонів, управління міграчією та надання притулку. Про иі вади регулювання єврозони вперше заговорили під час фінансової кризи 2008-2012 років, а прогалини Шенгенської системи виявилися під час кризи біжениів 2015-2016 років. Тому натепер актуально звернути увагу на дослідження показників та основних напрямків міграчійних потоків у Європі впродовж останніх років, а також на сучасну міграчійну проблему, що існує у країнах Європейського Союзу. Варто провести аналіз наукових досліджень із даної теми, проаналізувати проблеми інтеграиї біжениів у європейську спільноту, оскільки недавні теракти у Франиї й Австрії показують на неуживання мусульманських та європейських культур. У зв'язку із иим у статті розглянуто дії та позииї держав - учасниць Європейського Союзу щодо міграційної політики. У роботі досліджено головні тенденції міграчійної політики Європейського Союзу, насамперед зростання популярності радикальних поглядів вирішення проблеми масового напливу мігрантів. У статті звертається увага на бажання керівних держав - иленів Свропейського Союзу обмежити стихійний приплив нелегальних мігрантів із тих крайн, що перебувають на етапі розвитку, оскільки ие створює численні сочіальні, політичні, економічні, а також культурно-релігійні проблеми для країн Європейського Союзу, що ведуть до підриву національної безпеки держав-членів через загрозу терористичних актів.

Ключові слова: зовнішня політика, країни Європейського Союзу, міграційні потоки, мігранти, біженці, регулювання, нелегальна міграція, квотування.

Постановка проблеми. Свросоюз зараз відчуває наслідки організаційних і правових прогалин, які не вирішені в Шенгенській системі, а також наслідки суперечностей між державами в пошуку косенсусу 3 міграційного регулювання. 3 одного боку, право особи на вільний вибір місця проживання як одна із цінностей Свропейського Союзу (далі - СC) не може бути обмежене в демократичному суспільстві, а 3 іншого боку, дотримання цієї цінності нині суперечить можливостям і бажанню країн-членів приймати біженців та мігрантів, особливо з іншою культурою й етикою ставлення до праці. Недосконалість Шенгенської сис- теми та проблема пошуку компромісу між демократичністю та захистом суверенітету, між інтеграцією та захистом інтересів окремих держав-членів виявилися 3 початком масштабної міграційної кризи 2015 р. Ця криза призвела до розколу між багатьма країнами - членами ЄС, похитнула єдність Євросоюзу як демократичного цивілізаційного проєкту. Одним із негативних наслідків неспроможності старої еліти Свропи вирішити ці проблеми на ліберальних засадах стала втрата довіри з боку виборців до ліберально-демократичних сил. Такий висновок можна зробити зі стрімкого поширення в $\mathrm{CC}$ популізму, особливо правого. 
Інтенсифікація й динамізація міграційних потоків зумовили значний інтерес науковців до проблем міграції. Осмислення міграційних процесів здійснили у своїх працях: О. Ананьєва, М. Козловець, О. Малиновська, Л. Ороховська, О. Ференц, Т. Саррацин, Ч. Тейлор, М. Уолцер, В. Воронкова Ю. Кривенко, С. Мочерний, А. Семенов, Б. Лановик, В. Новік, С. Чехович та інші вітчизняні і закордонні правники.

Мета статті - дослідження причин сучасної міграційної кризи у країнах $\mathrm{CC}$, розгляд основних загроз підриву інтеграційних та демократичних засад, які можуть постати перед Європейським Союзом, а також пошук можливих способів їх недопущення й альтернативних механізмів вирішення проблем міграційної кризи.

Виклад основного матеріалу. Через погіршення соціально-економічних умов, загострення військових та політичних загроз у країнах Африки, Близького Сходу, як наслідок, підвищення нестабільності в цих регіонах, тривалий період відбувалось інтенсивне зростання міграційних потоків до СС Доки на піку свого розвитку (у 2015 р.) таке зростання призвело до кризи в цій сфері, яка проявилася в некерованості механізму міграційної політики як на наднаціональному, так і на національному рівнях. Виникла потреба оптимізації її нормативно-правових і організаційних засад. Щоби зрозуміти причини міграційної кризи, потрібно проаналізувати сучасне міграційне законодавство СС.

Ще на початку формування європейського міграційного права було запроваджено механізм вільного руху, який знайшов свій зовнішній вияв у Шенгенській системі нормативних актів. Вони становлять собою сукупність спільних прав i зобов'язань, обов'язкових до виконання в усіх країнах членах ЄС (ідеться про Угоду про поступове скасування перевірок на спільному кордоні від 19 червня 1985 р. - «Шенген I», Конвенцію про застосування Шенгенської угоди про поступове скасування перевірок на спільних кордонах від 19 червня 1990 р. - «Шенген II»). Ці нормативні акти заклали основи регулювання міграції, визначили умови і порядок пересування територією Шенгенського простору. Пізніше Амстердамським договором 1997 р. була запроваджена єдина політики 3 імміграції, яка увійшла до компетенції Європейського співтовариства. Отже, у цій сфері регулювання наднаціональні юридичні інструменти отримали пріоритет над національним законодавством.

Щодо інституту надання притулку, то вагомим документом у цій сфері імміграцій- ної політики є Дублінська угода 2003 р., якій передувала конвенція 1990 р. У конвенції містилися критерії, відповідно до яких державачлен визнається відповідальною за розгляд клопотань про надання притулку. Тобто питання надання чи ненадання притулку належить до національної компетенції кожної держави - члена СС. Дублінська конвенція лягла в основу формування права і політики надання притулку в СС [1, с. 276-278].

Ще одним важливим нормативно-правовим актом у цій сфері є Гаазька програма 2003 р., вона відносить до наднаціональної компетенції СС побудову загальної європейської системи притулку. Передбачається, що на теренах $\mathrm{CC}$ має діяти єдина процедура надання притулку та єдиний статус для осіб, що отримали притулок або субсидіарний захист. Найголовнішим натепер напрямом цієї Програми є інтеграція громадян третіх країн. Адже на тлі атаки 2 листопада 2020 р. в центрі Відня, нападу в соборі Ніцци в жовтні 2020 р., а також убивства французького вчителя за показ карикатур на пророка Мухаммеда питання інтеграції мігрантів має дуже вагоме значення для нормального співіснування із громадянами тієї держави Європейського Союзу, до якої вони прибули. Це ж питання, а також питання боротьби 3 нелегальною імміграцією, укладання міжнародних угод про реадмісію регулюється Лісабонським договором 2009 р. Проте зазначених вище базових актів із питань міграції недостатньо для вирішення міграційних проблем, потрібен консенсус між державами членами СС щодо запровадження конкретних дієвих механізмів подолання негативних наслідків міграції, передусім із третіх країн.

У міграційній політиці $\mathrm{CC}$ варто виділити два ключові напрями: регулювання внутрішньої європейської міграції громадян та регулювання імміграції із третіх країн. Щодо першого напряму, то така міграція сприяє інтеграційному процесу всередині ЄС. Оскільки створення міцного союзу, ліквідація внутрішніх кордонів, посилення соціальної й економічної взаємодії, розвиток співробітництва - усе це є цілями ЄС, то внутрішня міграція регулюється мінімальними обмеженнями. Так, для короткотермінового - до трьох місяців - перебування на території будь-якої країни Свросоюзу достатньо мати лише документ, що посвідчує особу. До того ж члени сімей громадян $\mathrm{CC}$, які є громадянами третіх країн, користуються тими ж правами, що й громадянин $\mathrm{CC,} \mathrm{з} \mathrm{яким} \mathrm{вони}$ пересуваються Європою [2, с. 138-144].

Триваліше проживання в іншій країні $\mathrm{CC}$ допускається за дотримання певних умов. Громадянин повинен або бути економічно 
активним, наприклад працевлаштованим чи самозайнятим, або мати достатні фінансові ресурси, медичну страховку, тобто перебувати в такому становищі, щоб мати змогу себе забезпечити, а не бути додатковим тягарем для системи соціального захисту країни перебування. Громадянин, який відповідає зазначеним умовам, може переїздити разом із членами сім'ї [2, с. 138-144]. Після 5 років безперервного проживання на території країни - члена громадянин $\mathrm{CC}$, особа та члени iї сім'ї, які дотрималися такої умову, отримують право постійного проживання в цій країні. Статус постійного мешканця дає можливість користуватися всією повнотою прав, зокрема й соціальним захистом та допомогою у здобутті освіти (гранти, кредити).

Окремо регулюється трудова міграція, оскільки однією із проблем для СС у сфері міграції $\epsilon$ нестача висококваліфікованих кадрів. Тому в рамках трудової міграції передбачені додаткові права, які покликані забезпечити притік робочої сили із третіх країн, а також не перешкоджати вільному перерозподілу працівників ву межах ЄС. Уточненню та кодифікації прав працівників, які пересуваються в межах $\mathrm{CC}$, та членів їхніх родин присвячено регламент, ухвалений у 2011 р. [3]. Він забороняє особливий порядок працевлаштування громадян інших країн $€ \mathrm{C}$, гарантує рівний доступ до працевлаштування, професійного навчання як мігрантів, так і їхніх дітей, рівні умови праці та її оплати, доступ до соціальних пільг, участь у профспілках.

Щодо імміграції із третіх країн, то у 2004 р. на регулювання в'їзду громадян інших країн в ЄС та їх перебування ухвалена Директива 2004/38/ЄС. Ї̈ положення були обов'язкові для включення у відповідні національні закони всіх держав - членів СС. Положеннями цієї директиви передбачалося: забезпечення рівноправності оплати праці трудових мігрантів із третіх країн із громадянами країн - членів СС; встановлення єдиних вимог для трудових мігрантів із третіх країн та громадян ЄС стосовно участі в об'єднаннях; обов'язкове медичне забезпечення для громадян третіх країн та країн - членів СС; право на освіту дітей; забезпечення нормальних житлових умов трудових мігрантів із країн членів $\mathrm{CC}$ та громадян країн-членів; право на соціальне страхування [4].

Як уже зазначалося, один із напрямів міграційної політики СС - це регулювання імміграції із третіх країн. У низці правових актів СС визначено спільні підходи до забезпечення легальної імміграції та гарантій прав мігрантів. Зокрема, у 2003 р. ухвалено директиву стосовно правового статусу громадян третіх країн, які тривалий час (не менше п'яти років) безперервно проживали на території країн-членів [5]. Ї̈̈ дія поширюється на громадян третіх країн, які мають стабільне і регулярне джерело доходу, медичну страховку, не становлять загрози безпеці чи громадському порядку держави проживання. Директива передбачає, що громадяни третіх країн, які мають дозвіл на проживання в одній із країн $\in C$, отримують право на пересування та проживання на території інших держав Свросоюзу. Також зрівняні соціальні й економічні права громадян та іммігрантів, а саме: право на працевлаштування та підприємницьку діяльність, освіту та професійне навчання, соціальний захист і основні види допомоги. У 2010 р. було розширено дію цієї директиви за колом осіб на користувачів міжнародного захисту, тобто біженців із третіх країн, якщо ними дотримується вимога щодо тривалості проживання в СС. Наступною директивою мігрантам надано право на возз'єднання сімей та гарантовано права осіб, які прибувають як члени їхніх сімей (Coucil Directive 2003/86/EC of 22 September 2003 on the right to family reunification).

Отже, міграційне право ЄС передбачає досить сприятливий порядок в'їзду та перебування на території країн Свросоюзу. Громадяни третіх країн не зазнають значних обмежень у разі міграції до СС, що цілком відповідає принципам свободи пересування та вибору місця проживання. Така міграційна політика призвела до великої кількості громадян третіх країн, що бажають переселитися на територію країн Свропи. Неконтрольований потік мігрантів призвів до перевантаження Свропи їх фінансовим забезпеченням, а також до суспільних конфліктів на грунті зіткнення різних культур та релігій.

Нелегальна міграція стала стійким і масштабним явищем, що впливає на соціальноекономічні та політичні процеси в багатьох країнах сучасного світу. За даними Міжнародної організації з міграції (далі - МОМ), міжнародне переселення досягає рекордних висот, число внутрішньо переміщених осіб перевищує 40 мільйонів осіб, а число біженців становить більше 22 мільйонів осіб [6]. Через неспроможність урядів країн - учасниць СС домовитися про спільні дії в багатьох країнах набирають популярності праворадикальні партії, які виступають за ізолювання держав та захист внутрішніх кордонів від мігрантів. Відсутність єдиного бачення процесу розселення великого потоку мігрантів та розбіжність щодо напрямів та пропорцій такого розселення призводять до нерівномірного навантаження на міграційні служби окремих країн Європи. Як наслідок, політика ізоляції набирає обертів, адже міграційна криза зму- 
сила деякі держави вдатися до практики відновлення контролю на внутрішніх кордонах. Відповідне право закріплене у ст. 23 Шенгенського кодексу (Schengen Borders Code). Наприклад, Німеччина відновлювала контроль на сухопутному кордоні 3 Австрією на період від 11 лютого до 11 травня 2017 р.; Австрія - зі Словенією й У горщиною. Франція через постійну терористичну загрозу відновила контроль на всіх внутрішніх кордонах на період із 27 лютого до 15 липня 2017 р. [7].

Такий засіб боротьби 3 міграційною кризою підтримують європейські праворадикальні політичні сили, вони вважають за потрібне обмежити міграційни потоки всіма можливими рішучими заходами, навіть якщо вони можуть поставити під удар наднаціональні інтереси. I така позиція має підтримку серед населення в умовах, коли низка держав СС виділяють значні кошти для оперативного реагування й облаштування спеціальних пунктів прийому біженців і забезпечення необхідною гуманітарною допомогою (харчування та медичне обслуговування) [8, с. 334-338]. Найбільше така тенденція простежується в Німеччині, яка відіграє в Євросоюзі особливу роль лідера та спонсора водночас. На тлі міграційної кризи там зросла популярність ультраправої партії «Альтернатива для Німеччини».

Окрім Німеччини, дуже потерпає від недосконалості Шенгенської системи Італія, куди прямують більшість мігрантів з Африки через Лівію. Ця середземноморська країна наполягає на необхідності перенесення міграційних офісів за межі СС для відбору мігрантів, і цю позицією підтримує Сврокомісія. 3 початку 2018 р. до Греції через Егейське море прибуло 120 тис. мігрантів зі 130 тис. загалом по СC. За даними OOH (UNHCR), ця кількість мігрантів за два місяці дорівнювала кількості мігрантів за шість місяців 2015 р. Таке перевантаження створило значну напругу у відносинах із партнерами по $\mathrm{EC}$, які звинувачують Афіни в навмисній нереєстрації мігрантів як у «країні першого прибуття», їх транзиті через свою територію. Греція не погоджується перетворюватися на центр СС для мігрантів і вимагає солідарності. Конфлікт настільки загострився, що Афіни відкликали свого посла в Австрії.

Країни, що найбільше потерпають від біженців: Німеччина, Франція, Італія та Греція, запропонували механізм квотування мігрантів у всіх кранах ЄC. Через нерівномірний розподіл мігрантів у Свропейському Союзі і надмірне навантаження на Італію та Грецію з'явилась можливість застосування ч. 3 ст. 78 Лісабонського договору, що стало лише частковим вирішенням цієї про- блеми. Ця стаття передбачає, якщо один чи більше членів $\mathrm{CC}$ зіткнулися з надзвичайною ситуацією, пов'язаною з напливом громадян третіх країн, Свропейська рада за пропозицією Європейської комісії може вжити запобіжних заходів [1, с. 276-278]. Тому СС розробив принцип квотного розподілу мігрантів, але цей механізм є недосконалим. Адже, по-перше, це спричинило ще більше суперечностей у відносинах між державами - членами $\mathrm{CC}$, по-друге, такий механізм ставить під удар свободу пересування та вибору місця проживання. У 2017 р. Словаччина й Угорщина подали скарги стосовно міграційної політики ЄС і квот на мігрантів, однак Європейський суд відхилив їхні скарги. Свропейський суд також дійшов висновку, що ЄС мав право давати вказівки національним урядам стосовно прийняття в рамках квот переважно сирійських біженців, які перебувають в Італії та Греції [2, с. 251-156].

Але більшість лідерів у СС ухвалювали рішення на власний розсуд, ігнорували квоти. Річ у тім, що квотний підхід суперечить базовим засадам свободи вибору проживання - добровільності з боку самих мігрантів. На практиці виявилося, що більшість біженців з Африки та Близького Сходу бажають отримати притулок або дозвіл на проживання суто в Німеччині, Швеції або Британії, а решта країн слугують для них тільки транзитними зонами.

\section{Висновки}

Правовою основою політики СС у сфері міграції є Конвенція ООН щодо біженців та Свропейська конвенція з прав людини. Для подолання міграційної кризи зроблено спроби відновлення внутрішніх кордонів, уведення квотування мігрантів, також розглядалося питання про перенесення міграційних центрів за межі СС. Крім того, велися переговори з Італією, Австрією та Грецією щодо угод про реадмісію біженців, аналогічних досягнутій СС із Туреччиною у 2016 р., на випадок, якщо Німеччина відмовить їм у притулку. Країни СС намагаються усунути основні причини кризи, а також значно збільшують допомогу для людей, які потребують гуманітарної допомоги всередині і за межами ЄC. Уживаються заходи з переселення осіб, які шукають притулку в Свропі, розселяють людей із сусідніх країн, які претендують на притулок, щоби зменшити навантаження на окремі країни. Крім того, останнім часом загострюється проблема співіснування різних культур і релігій, у зв'язку із чим постало питання адаптації й інтеграції мігрантів із місцевим населенням. Водночас $Є$ С посилює безпеку на кордонах, у боротьбі з незаконним 
ввозом мігрантів, пропонує безпечні способи для людей, щоби легально потрапити в СС.

Отже, у результаті дослідження розвитку міграційної політики Європейського Союзу можна зробити висновок, що основними її напрямами реагування на міграційну кризу є: зменшення кількості нелегальних мігрантів, управління кордонами, загальна політика щодо притулку та легальної міграції, зокрема й інтеграція та розвиток у країнах походження, а також запровадження інституту квотування мігрантів. Свросоюзу варто створити інтегровану та денаціоналізовану систему надання притулку та координації міграційної політики на рівні Брюсселя, для захисту спільного кордону.

\section{Список використаних джерел:}

1. Безушко М. Міграційна політика $€ C$ : виникнення та проблеми сьогодення. Юридичний науковий електронний журнал. 2020. № 1. С. 276-278.

2. Малиновська О. Міграційна політика: глобальний контекст та українські реалії : монографія. Київ : НІСД, 2018. 472 с.

3. Regulation (EU) № 492/2011 on freedom of movement of workers. URL: http://eur-lex.europa. eu/legal-content/EN/TXT/?uri=celex:32011R0492 (дата звернення: 28.10.2020).

4. Директива 2004/38/EC Европейского парламента и Совета от 29 апреля 2004 г. URL: https://eulaw.edu.ru/spisok-dokumentov-popravu-evropejskogo-soyuza/dokumenty-o-pravahcheloveka-i-grazhdanina/normativnye-akty-osvobode-peredvizheniya-tovarov-lits-i-uslug/ direktiva-2004-38-es-evropejskogo-parlamentai-soveta-ot-29-aprelya-2004-g/ (дата звернення: 29.10.2020)

5. Директива 2003/109/EC Европейского Совета от 25 ноября 2003 г. URL: http://iconinvest.ru/ zakonodatelstvo/30-zakonodatelstvo/direktiva2003-109-es-soveta-ot-25-noyabrya-2003-g-o-statusegrazhdan-tretikh-stran-prozhivayushchikh-nadolgosrochnoj-osnove-perevod-na-russkij-yazyk/53direktiva-2003-109-es-soveta-ot-25-noyabrya-20) (дата звернення: 29.10.2020).

6. The International Organization for Migration. URL: http://www.iom.int/ (дата звернення: 30.10.2020).

7. Member States' notifications of the temporary reintroduction of border control at internal borders pursuant to Article 25 et seq. of the Schengen Borders Code / European Commission. URL: https:// ec.europa.eu/home-affairs/sites/homeaffairs/ files/what-we-do/policies/borders-and-visas/ schengen/reintroduction-border-control/docs/ms notifications_-_reintroduction_of_border_control_ en.pdf (дата звернення: 30.10 .2020 ).

8. Алгаш В., Піттель А. Сучасна міграційна криза як виклик для Європейського Союзу. Підприємниитво господарство $і$ право. 2019. № 12. C. $334-338$.

\section{Olesia Protsenko. Migration policy of the European Union}

The European Union protects the right of people to freedom of movement as one of the key democratic values and an inalienable natural right, so its migration policy is aimed at ensuring this value. Abandonment of this value, the creation of restrictions on movement will undermine the whole EU as an integration union, because only the freedom of movement of goods and services will remain, and the EU will become a purely customs union. In addition, it will negatively affect the Union's reputation as a democratic project of integration of states and a defender of democratic values. Restoring the EU's internal borders as a means of protection against the negative effects of migration destroys the solidarity of states, undermines their openness to cooperation and exchange, isolates states within the EU and undermines the very principle of freedom of movement in the European Union. The waiver of internal border controls under the 2006 Schengen Agreement limited state sovereignty in favor of freedom of movement, and states agreed to such a restriction, recognizing the need for such a step and its importance in the context of integration. So why are they now ready to move away from such a position and choose an isolationist course? This seems to be the quickest way to respond to the migration crisis caused by the Schengen countries erasing internal borders without creating the necessary legal and institutional framework and without agreeing on collective institutions to protect external borders, manage migration and provide asylum. These shortcomings in the regulation of the euro area were first discussed during the financial crisis of 2008-2012, and the gaps in the Schengen system were revealed during the refugee crisis of 2015-2016. Therefore, it is important to pay attention to the study of indicators and main directions of migration flows in Europe in recent years, as well as the current migration problem that exists in the EU. It is necessary to analyze research on this topic, to analyze the problems of integration of refugees into the European community, as recent terrorist attacks in France and Austria show the non-use of Muslim and European cultures. In this regard, this article examines the actions and positions of the member states of the European Union on migration policy. The paper examines the main trends in EU migration policy, primarily the growing popularity of radical viewes on solving the problem of mass influx of migrants. The article drawes attention to the desire of the leading EU member states to limit the spontaneous influx of illegal migrants from developing countries, as this creates numerous social, political, economic and cultural-religious problems for EU countries that lead to the undermining of national security. Member States due to the threat of terrorist acts.

Key words: foreign policy, European Union countries, migration flows, migrants, refugees, regulation, illegal migration, quotas. 